\title{
Az értelmiség szerepe, felelőssége
}

\section{HOZZÁSZÓLÁS PIERRE LÉVY „AZ ÉRTELMISÉG ÚJ FELELŐSSÉGE A KOMMUNIKÁCIÓ KORÁBAN” CÍMÜ ÍRÁSÁHOZ}

\section{Szerzői információ:}

\begin{abstract}
Alföldi István
A Neumann János Számítógép-tudományi Társaság ügyvezető igazgatója a Budapesti Múszaki Egyetemen villamosmérnöki és mérnök-tanári, majd a Budapesti Közgazdaságtudományi Egyetemen mérnök-közgazdász végzettséget szerzett. Szakmai munkáját a KSH-ban kezdte, ahol elốször programozással, késóbb információs, majd adatkezelő rendszerek tervezésével és fejlesztésével foglalkozott. 1986 és 1990 között a KSH fejlesztési igazgatójaként, majd a KFKI MSZKI projekt-menedzsereként tevékenykedett. Részt vett a kormányzati informatikai rendszer kialakításában és a büntetés-végrehajtás országos informatikai rendszerének megtervezésében. 1993tól különbözô vállalatoknál töltött be informatikai vezetôi munkaköröket. Nevéhez fúződik a „Digitális Esélyegyenlőség” mozgalom hazai beindítása és ennek keretében az Európai Számítógép-használói Jogosítvány (ECDL) hazai bevezetése.

E-mail: istvan.alfoldi@njszt.hu
\end{abstract}

Így hivatkozzon erre a cikkre:

Alföldi István. „Az értelmiség szerepe, felelőssége”.

Információs Társadalom VIII, 4. szám (2008): 12-14.

$\mathbf{L}$

https://dx.doi.org/10.22503/inftars.VIII.2008.4.2

A folyóiratban közölt müvek

a Creative Commons Nevezd meg! - Ne add el! - Így add tovább! 4.0

Nemzetközi Licenc feltételeinek megfelelően használhatók. 
Alföldi István

\section{Az értelmiség szerepe, felelós sége}

Újra kell-e fogalmazni az értelmiség szerepét? Mitól más a kommunikáció kora, mitól más az információs társadalom, mint az ezt megelôzố korok? Van-e olyan minôségi különbség, amely alapvetốen megváltoztatja az alkalmazkodási, fejlôdési, beilleszkedési szokásokat? A válasz: igen és nem. Az igent mindenki azonnal érteni véli, hiszen naponta nő azon fogalmak száma és mögöttes tartalma, amelyekról elmondható: „eddig még nem volt”. Az információs társadalom definíciója is számos alakban létezik, de kérdezzünk csak meg két embert, biztosan legalább két különbözô megközelítés lesz az eredmény. Ahhoz tehát, hogy az IGEN választ értelmezni lehessen, íme egy lehetséges definíció, a „3 I” alapú meghatározás. Az Infrastruktúra, Igény, Ismeret egysége az igényben megvalósuló motiváció és tartalom, a szükséges ismeretek többszintűsége és sokszínúsége együttesen jól leírja azt a valamit, amit információs társadalomnak nevezünk. Az értelmiség szerepe minden „I”-ben más módon, de egyértelmúen tetten érhetô. Az is világos, hogy mely területek azok, ahol a feleloósség és a szerep újrafogalmazása elkerülhetetlen.

A jobb megértéshez vessünk egy pillantást arra, hol is tart ma Magyarországon az információs társadalom, létezhet-e digitális esélyegyenlőség, és mit kell érte tenni. Egy szociológus-politikus, Csepeli György az információs társadalom rétegzôdéséról szóló előadásában reális képet festett a hazai társadalom rétegeiról, számba véve a virtuális térbe átköltözött „,addiktokat” és az „érintetleneket” egyaránt.

A kettô közötti arany középutat - a produce és a consume igékból származtatott elnevezéssel - a „prosumerek” jelentik, akik nemcsak fogyasztják az internetes tartalmakat, számítógépes fejlesztéseket, hanem hozzájárulnak azok „termeléséhez” is: közéjük sorolhatók a szakmai felhasználó „irodai munkások”, a praktikum elve alapján számítógépező „tájékozódók”, valamint azok is, akik csak játszani használják a számítógépet. Az érintetlenek között - akik ma még a társadalom többségét alkotják - vannak elérhetetlenek, akik semmilyen körülmények között nem vonhatók be az információs társadalomba. Vannak továbbá a közvetítésre szorulók és az integrálhatók, akikkel kapcsolatban az előadó külön hangsúlyozta az „írástudók” és a kormányzat felelősségét. Mindezt annak érdekében, hogy valóban létrejöhessen a digitális esélyegyenlôség, legyớzhetố legyen az újtól való szorongás éppúgy, mint az ún. digitális bolsevizmus és a tudatlanság - nem titkolva persze, hogy az aggályok közül több nagyon is jogos: ilyenek a biztonság hiánya, a totális ellenốrzöttség érzése, az információs környezetszennyezés is.

Szokás a felgyorsult idốre, a nagyságrendekkel megnövekedő információmennyiségre, az internetvilágba való bezártságra utalni, amikor az élet minôségi változásairól beszélünk. Ezek igazi kihívások az értelmiségi léttel szemben. Hogyan teljesítsünk tisztességesen, ha naponta legalább 50-100 fontos és legalább annyi kéretlen elektroni- 
kus levelet kapunk? Hogyan ốrizzük meg személyes integritásunkat, ha különböző közösségi oldalakon regisztráljuk magunkat, vagy csak egyszerúen árut rendelünk? Egyáltalán mennyire van védve a magánéletünk, ha kommunikálunk? Az értelmiség vagy inkább a modern kori írástudók felelốssége igen nagy abban, hogy ezek a kérdések valóságos válaszokkal legyenek tisztázhatók. Amikor digitális analfabetizmusról beszélünk, nemcsak a pillanatnyi technikai eszközök nyújtotta lehetőségeknek a kelló ismeretek, elegendố tudás hiányában előálló kihasználatlanságáról beszélünk, hanem a félelem, a frusztráció és a tartalmatlanság valóságáról is.

Világosan látni kell azonban, hogy nem egyedül a technológia rohamos és nem lassuló fejlődése okozza a kihívást. A környezeti lábnyomot bőven maga mögött hagyó, globálissá vált világ olyan magatartásminták kialakulásához járul hozzá, amelyek ellentmondanak az emberi lét hosszú távú fenntarthatóságának. Az értelmiség - vagy amit annak gondolunk - szerepe és megkerülhetetlen felelóssége tehát fokozottan fontossá válhat.

Haladéktalanul meg kell tehát teremteni az egyensúlyt, át kell hidalni a szakadékot a digitális analfabéták, a „múlt századi berögződések rabjai”, illetve a 21. századi technikai forradalom hívei és haszonélvezói között. Szervezetten, elkötelezetten és a civil társadalomért vállalt felelósségtudattal rövid idô - mintegy három év - alatt elérhetố lehet az információs társadalom három alappillérének megszilárdítása: a megfelelő infrastruktúra kiépítése, az internethasználathoz, az irodai funkciók alkalmazásához szükséges ismeretek milliók számára történő átadása, valamint - és ma talán ez jelenti a legnagyobb kihívást - az igény felkeltése. Ha pedig mindez megvan, vagyis legalább hárommillió digitális írástudó, e-polgár lesz Magyarországon, akkor joggal mondhatjuk majd magunkat a digitális demokrácia országának, amelynek lakói az egyébként elkerülhetetlen technikai forradalomnak nem ellenállói vagy kiszolgáltatott áldozatai, hanem haszonélvezói lesznek.

Ebból a szempontból tehát az alapkérdésre határozott NEM-mel kell válaszolni. A hagyományos értékek fontosságának szükségszerú felértékelódése nélkül a világ élhetetlenné válhat. Nemhogy csökkenne tehát az értelmiség felelőssége, éppen ellenkezóleg: inkább nô, hiszen itt már régen nem egyszerú mennyiségi, hanem sokkal inkább alapvetô minôségi változásról van szó.

E célt szolgálja a Neumann János Számítógép-tudományi Társaság már 2007 elején meghirdetett, társadalmi összefogást, politikai felelősségvállalást sürgetố, az esélyegyenlőség megteremtését célzó kezdeményezéseket múködtető, befogadó és támogató „Digitális Esélyegyenlőség” programja, amellyel csatlakozik az Európai Bizottság által meghirdetett e-inclusion (e-befogadás) évéhez, és amelynek célja teljes összhangban van a lisszaboni célkitúzésekkel, az Európai Bizottság i2010 stratégiájában foglaltakkal. 